ACTA UNIVERSITATIS WRATISLAVIENSIS

No 3978
PRZEGLĄD PRAWA I ADMINISTRACJI CXX/1
WROCŁAW 2020

https://doi.org/10.19195/0137-1134.120.37

\author{
MARCIN MIEMIEC \\ ORCID: 0000-0002-9100-0895 \\ Uniwersytet Wrocławski \\ Instytut Nauk Administracyjnych \\ Zakład Prawa Administracyjnego
}

\title{
CENTRUM USŁUG SPOŁECZNYCH JAKO FORMA ORGANIZACYJNA ADMINISTRACJI ŚWIADCZĄCEJ
}

\begin{abstract}
Abstrakt: Centrum usług społecznych wprowadzono do porządku prawnego na mocy ustawy z dnia 19 lipca 2019 roku o realizowaniu usług społecznych przez centrum usług społecznych. Jest to jednostka organizacyjna tworzona fakultatywnie przez radę gminy, świadcząca usługi społeczne wykraczające poza zakres pomocy społecznej, wykonywane dotychczas w gminie przez różne podmioty, szczególnie przez ośrodek pomocy społecznej, a także przejęte od powiatu na podstawie porozumienia. Regułą jest tworzenie centrum przez przekształcenie gminnego ośrodka pomocy społecznej i świadczenie przez centrum usług na obszarze jednej gminy. Centrum może być także utworzone jako nowa jednostka organizacyjna gminy lub większej liczby gmin, powołana do świadczenia usług na tym terytorium. W tym zakresie ustawa ma charakter porządkujący, ponieważ nawiązuje bądź odsyła do obowiązującej regulacji prawnej innych ustaw. Do zakresu zadań centrum usług społecznych należy także koordynacja usług społecznych świadczonych przez inne podmioty na obszarze jego działania. W tym celu ustawa wprowadza mechanizmy prawne umożliwiające wykonywanie tej funkcji, szczególnie takie, jak programowanie usług społecznych czy planowanie organizowania społeczności lokalnej.
\end{abstract}

Słowa kluczowe: administracja publiczna, administracja świadcząca, pomoc społeczna, zabezpieczenie społeczne, usługi społeczne, centrum usług społecznych, organizator społeczności lokalnej.

1. Do zadań współczesnej administracji publicznej należy zaspokajanie podstawowych potrzeb materialnych osób, które nie są w stanie tego uczynić w ramach własnych możliwości. Dotyczy to w szczególności: przymusowych i powszechnych ubezpieczeń społecznych, związanych z zatrudnieniem; zaopatrzenia społecznego niezwiązanego z zatrudnieniem, w związku z utratą możliwości zarobkowania z tytułu wieku bądź stanu zdrowia. Systemy te uzupełnia pomoc społeczna. Wymienione zadania usytuowane są w obszarze zabezpieczenia społecznego ${ }^{1}$. Pomoc społeczna ukształtowała się $\mathrm{w}$ toku ewolucji. Jej pierwsze formy stanowiły publiczna opieka społeczna, a wcześniejszej dobroczynność podmiotów

1 J. Jończyk, Prawo zabezpieczenia społecznego, Kraków 2003, s. 7 n. 
prywatnych ${ }^{2}$. Pomoc społeczna jest uregulowana aktami normatywnymi prawa krajowego i międzynarodowego.

W charakterystyce krajowych podstaw prawnych pomocy społecznej należy wyjść od art. 2 Konstytucji Rzeczypospolitej Polskiej, według którego Rzeczpospolita Polska jest demokratycznym państwem prawnym, urzeczywistniającym zasady sprawiedliwości społecznej. Jest więc nie tylko państwem demokratycznym i prawnym, ale także socjalnym i opiekuńczym. Konstytucyjna regulacja socjalna jest rozwinięta w rozdziale II „Wolności, prawa i obowiązki człowieka i obywatela”, w podrozdziale „Prawa i wolności ekonomiczne, socjalne i kulturalne"3. Słabość regulacji konstytucyjnej polega na tym, że w kwestiach szczegółowych odsyła ona do regulacji ustawowej ${ }^{4}$.

Znaczenie dla pomocy społecznej ma także Europejska Karta Społeczna Rady Europy z 18 października 1961 roku, ratyfikowana przez Polskę w 1999 roku5 Zobowiązuje ona sygnatariuszy do zapewnienia osobom bez dostatecznych zasobów, niezdolnym do zapewnienia ich sobie z innych źródeł, pomocy w ramach systemu zabezpieczenia społecznego, także w formie udzielania porad bądź pomocy niezbędnej do zapobieżenia, usunięcia stanu potrzeby czy ulżenia sytuacji osobistej lub rodzinnej osób potrzebujących, także obywatelom innych państw sygnatariuszy, przebywającym legalnie na obszarze tych państw. Sygnatariusze zobowiązali się popierać lub organizować służby publiczne właściwe w tych sprawach, przyczyniające się do dobrobytu i rozwoju jednostek, grup społecznych i do ich adaptacji w środowisku społecznym, jak również zachęcać jednostki i organizacje dobroczynne czy inne podmioty do uczestnictwa w ustanawianiu i utrzymywaniu takich służb.

2. Wykonywanie zadań z zakresu pomocy społecznej w Polsce należy przede wszystkim do organów administracji rządowej i samorządowej, realizujących je bezpośrednio bądź za pomocą ich jednostek organizacyjnych. Organy i podmioty publiczne w wykonywaniu zadań pomocy społecznej, stosownie do postanowień Europejskiej Karty Społecznej, współdziałają także z organizacjami pozarządowymi, Kościołem katolickim, innymi kościołami, związkami wyznaniowymi, z osobami fizycznymi i prawnymi.

Rodzaje tych zadań i ich podział są uregulowane w ustawach ustrojowego prawa administracyjnego oraz $\mathrm{w}$ ustrojowej regulacji ustaw materialnego prawa administracyjnego, przede wszystkim w ustawie z dnia 12 marca 2004 roku o pomocy społecznej i w aktach wykonawczych do tej ustawy.

2 I. Sierpowska, Prawo pomocy spolecznej, Warszawa 2008, s. 13 n.; W. Muszalski, Prawo socjalne, Warszawa 2006, s. $171 \mathrm{n}$.

3 Zob. M. Miemiec, Prawo pomocy społecznej, [w:] Materialne prawo administracyjne, red. M. Miemiec, Warszawa 2019, s. $121 \mathrm{n}$.

4 B. Banaszak, Prawo konstytucyjne, Warszawa 2008, s. 240 n.

5 Dz.U. Nr 8, poz. 67. 
Istotną rolę pośród publicznych podmiotów pomocy społecznej odgrywają jednostki samorządu terytorialnego, a konkretnie ich organy i samorządowe jednostki organizacyjne. Zadania z zakresu pomocy społecznej wykonywane są na każdym stopniu samorządu terytorialnego — przez samorząd gminny, samorząd powiatowy i samorząd województwa. Stanowią o tym przepisy ustawy z dnia 8 marca 1990 roku o samorządzie gminnym ${ }^{6}$, ustawy z dnia 5 czerwca 1998 roku o samorządzie powiatowym ${ }^{7}$ i ustawy z dnia 5 czerwca 1998 roku o samorządzie województwa ${ }^{8}$.

Ustawa o pomocy społecznej przyjmuje, że podstawowymi formami organizacyjnymi realizacji omawianych zadań są: w samorządzie województwa - regionalny ośrodek polityki społecznej (art. 113 ups), w samorządzie powiatowym — powiatowe centrum pomocy rodzinie (art. 112 ups), w samorządzie gminnym — ośrodek pomocy społecznej (art. 110 ust. 1 ups). Zadania z zakresu pomocy społecznej wykonują też inne samorządowe jednostki organizacyjne, szczególnie dom pomocy społecznej, placówka specjalistycznego poradnictwa, w tym rodzinnego, ośrodek wsparcia czy ośrodek interwencji kryzysowej.

3. W systemie samorządu terytorialnego zadania z zakresu pomocy społecznej wykonują przede wszystkim gminy. Jest to zgodne z zasadą subsydiarności. Gminy, ich organy, ich aparat wykonawczy i jednostki organizacyjne są bowiem pośród podmiotów publicznych usytuowane terytorialnie najbliżej osób korzystających z pomocy społecznej.

Według art. 7 ust. 1 usg do zadań własnych gminy należy zaspokajanie zbiorowych potrzeb wspólnoty. Są to między innymi sprawy pomocy społecznej, w tym ośrodków i zakładów opiekuńczych (pkt 6), wspierania rodziny i systemu pieczy zastępczej (pkt 6a), polityki prorodzinnej, w tym zapewnienia kobietom w ciąży opieki socjalnej, medycznej i prawnej (pkt 16).

Ustawa o samorządzie gminnym i pozostałe ustawy samorządowe odsyłają do ustaw określających obowiązkowe zadania jednostek samorządu terytorialnego. W rozpatrywanym zakresie jest to przede wszystkim ustawa o pomocy społecznej oraz ustawa z dnia 9 czerwca 2011 roku o wspieraniu rodziny i systemie pieczy zastępczej ${ }^{9}$.

Artykuł 9 ust. 1 usg stanowi, że w celu wykonywania zadań gmina może tworzyć jednostki organizacyjne, a także zawierać umowy z innymi podmiotami, $\mathrm{w}$ tym $\mathrm{z}$ organizacjami pozarządowymi ${ }^{10}$. Jest to zgodne $\mathrm{z}$ regulacją art. 169 ust. 4 Konstytucji, według którego ustrój wewnętrzny jednostek samorządu terytorialnego określają, w granicach ustaw, ich organy stanowiące. Tego rodzaju kompetencje określane są w literaturze jako władztwo organizacyjne. Polega ono na

${ }^{6}$ Dz.U. z 2019 r. poz. 506 (dalej: usg).

7 Dz.U. z 2019 r. poz. 511 (dalej: usp).

8 Dz.U. z 2019 r. poz. 512 (dalej: usw).

9 Dz.U. z 2019 r. poz. 1111.

10 Przepisy o takiej treści zawarte są w pozostałych ustawach samorządowych. 
możności dokonywania wyboru przez jednostkę samorządu terytorialnego form organizacyjnoprawnych wykonywania zadań publicznych oraz wyboru między bezpośrednim wykonywaniem takich zadań a zlecaniem ich wykonywania w drodze umownej innym podmiotom. Nie dotyczy to wykonywania zadań zleconych z zakresu administracji rządowej. Zgodnie z zasadą legalności władztwo samorządu terytorialnego wykonywane jest na podstawie i w granicach ustaw. Obejmuje to także omawianą sferę. Można więc przyjąć, że brak ustawowej regulacji ustrojowoprawnej, czyli milczenie ustawodawcy w jakimś obszarze zadań jednostki samorządu terytorialnego, stwarza możliwość regulacji dokonanej przez właściwe organy $\mathrm{w}$ formie aktu prawa miejscowego czy aktu organizacyjnego $\mathrm{w}$ innej formie prawnej. W orzecznictwie sądowoadministracyjnym jest to odnoszone na ogół do statutu jednostki samorządu terytorialnego ${ }^{11}$.

W tej kwestii Rada Legislacyjna w stanowisku RL-035-18-15 z dnia 19 lutego 2016 roku, obejmującym szerszą problematykę upoważniania do wydawania aktów podustawowych, stwierdziła między innymi, że:

[Przepis] art. 169 ust. 4 [Konstytucji] powinien być traktowany jako konstytucyjne upoważnienie do wydania aktu prawa miejscowego. Dopuszczalne jest wydanie aktu regulującego „ustrój wewnętrzny jednostki samorządu terytorialnego” bezpośrednio na podstawie ww. przepisu Konstytucji. Nie ma w tym zakresie wymogu istnienia upoważnienia ustawowego. Ustawodawca nie może również pozbawić jednostek samorządu prawa do wydawania ww. aktów ${ }^{12}$.

W literaturze reprezentowane jest także stanowisko, odniesione do materii statutowej, oparte o art. 169 ust. 4 Konstytucji RP. Wynika z niego, że skoro według tego przepisu ustrój wewnętrzny jednostek samorządu terytorialnego jest regulowany w granicach ustaw przez ich organy stanowiące, to owe granice powinny być wyraźnie ustawowo określone. Sferę samodzielności ustrojowej jednostek samorządu terytorialnego ograniczają ustawowe zakazy i ograniczenia ${ }^{13}$.

Odnosząc te rozważania do ustroju gminy, można przyjąć, że istotą jej władztwa organizacyjnego są kompetencje organów gminy, będącej prawnie samodzielnym, zdecentralizowanym podmiotem administracji publicznej, do regulacji spraw ustrojowych gminy według ich uznania ograniczonego przepisami ustawowymi. Władztwo to dotyczy w zasadzie spraw wewnętrznych, ale może wykroczyć poza ten obszar, gdy obejmuje prawne formy współdziałania z podmiotami zewnętrznymi, przede wszystkim z jednostkami samorządu terytorialnego.

Przyjmując takie założenia, należy mieć zawsze na względzie relatywność władztwa organizacyjnego gminy, polegającą na jego ograniczeniu przez prawo

11 Zob. na przykład wyrok z dnia 7 maja 2008 roku WSA w Gorzowie Wielkopolskim, sygn. akt II SA/Go 169/08, LEX nr 519061; wyrok NSA z dnia 24 lutego 2014 roku, sygn. akt II OSK 2911/13, LEX nr 1450919.

12 „Przegląd Legislacyjny” 2017, nr 1, s. 133-148.

13 B. Jaworska-Dębska, Glosa do wyroku NSA z dnia 21 listopada 2013 r., II OSK 1887/13, „Samorząd Terytorialny” 2015, nr 3, s. 87-94. 
powszechnie obowiązujące. Samorządna pozycja gminy nie może bowiem kolidować z koniecznością zapewnienia jednolitości strukturalnej, przejrzystości, uproszczenia struktur organizacyjnych czy gospodarności administracji publicznej. Przykładami zewnętrznej, ustawowej determinacji organizacji gminy są na przykład: obowiązek tworzenia komórek organizacyjnych, takich jak ośrodek pomocy społecznej, urząd stanu cywilnego, biuro meldunkowe; obowiązek organizacyjnego dostosowania się do określonych procedur, na przykład wynikających z prawa zamówień publicznych.

Obydwie kategorie regulacji prawnej - ustawowa o charakterze ogólnym oraz gminna o charakterze szczegółowym - powinny zabezpieczać byt gminy jako organizacji zdolnej do wykonywania zadań publicznych. Ujmując władztwo organizacyjne $\mathrm{z}$ tego punktu widzenia, za istotne należy uznać prawo wspólnoty samorządowej do samodzielnej, w granicach ustawowo określonych, obsady personalnej jej organu uchwałodawczego i wykonawczego. Są to także kompetencje w zakresie zabezpieczenia zdolności świadczącej gminy, czyli ustalanie wewnętrznego podziału terytorialnego, struktury i zasad współdziałania organów uchwałodawczych i wykonawczych, organizacji i funkcjonowania administracyjnego i usługowego aparatu wykonawczego. W tym zakresie gminy powinny mieć szeroki zakres swobody organizacyjnej ujmowanej statycznie (struktura) i dynamicznie (funkcjonowanie), wyrażanej w statucie gminy, w regulaminach czy innych aktach organizacyjnych gminnych zakładów i pozostałych jednostek administracyjnych. Granice tego władztwa są określone przede wszystkim w komunalnym prawie ustrojowym, komunalnym prawie gospodarczym, a także w materialnym prawie administracyjnym.

4. Gmina wykonuje zadania z zakresu pomocy społecznej, posługując się głównie ośrodkiem pomocy społecznej, w którym mogą zostać wyodrębnione zespoły realizujące zadania ośrodka w zakresie pracy socjalnej i integracji społecznej, a mianowicie: w zakresie pracy socjalnej, w zakresie usług pomocy społecznej bądź zespół realizujący obydwie kategorie zadań (art. 110 lit. a) ups). W obszarze pomocy społecznej gmina może tworzyć też inne jednostki organizacyjne, jak na przykład ośrodek wsparcia (art. 51 n. ups), mieszkanie chronione (art. 53 ups). Ustawa o pomocy społecznej dokonuje podziału zadań z zakresu jej regulacji, zgodnie z zasadami przyjętymi w Konstytucji i w usg, na zadania własne obowiązkowe i dobrowolne, a także na zadania z zakresu administracji rządowej.

Według art. 17 ust. 1 ups do zadań własnych gminy o charakterze obowiązkowym należą: opracowanie i realizacja gminnej strategii rozwiązywania problemów społecznych ze szczególnym uwzględnieniem programów pomocy społecznej, profilaktyki i rozwiązywania problemów alkoholowych i innych, których celem jest integracja osób i rodzin z grup szczególnego ryzyka; sporządzanie oceny w zakresie pomocy społecznej; udzielanie schronienia, zapewnienie posiłku oraz niezbędnego ubrania osobom tego pozbawionym; przyznawanie i wypłacanie zasiłków okresowych; przyznawanie i wypłacanie zasiłków celowych; 
przyznawanie i wypłacanie zasiłków celowych na pokrycie wydatków powstałych w wyniku zdarzenia losowego; przyznawanie i wypłacanie zasiłków celowych na pokrycie wydatków na świadczenia zdrowotne osobom bezdomnym oraz innym osobom niemającym dochodu i możliwości uzyskania świadczeń na podstawie przepisów o świadczeniach opieki zdrowotnej finansowanych ze środków publicznych; przyznawanie zasiłków celowych w formie biletu kredytowanego; opłacanie składek na ubezpieczenia emerytalne i rentowe za osobę, która zrezygnuje z zatrudnienia w związku z koniecznością sprawowania bezpośredniej, osobistej opieki nad długotrwale lub ciężko chorym członkiem rodziny oraz wspólnie niezamieszkującymi matką, ojcem lub rodzeństwem; praca socjalna; organizowanie i świadczenie usług opiekuńczych, w tym specjalistycznych, w miejscu zamieszkania, z wyłączeniem specjalistycznych usług opiekuńczych dla osób z zaburzeniami psychicznymi; prowadzenie i zapewnienie miejsc w mieszkaniach chronionych; sprawienie pogrzebu, w tym osobom bezdomnym; kierowanie do domu pomocy społecznej i ponoszenie odpłatności za pobyt mieszkańca gminy w tym domu; pomoc osobom mającym trudności w przystosowaniu się do życia po zwolnieniu z zakładu karnego; sporządzanie sprawozdawczości oraz przekazywanie jej właściwemu wojewodzie, w formie dokumentu elektronicznego, z zastosowaniem systemu teleinformatycznego; utworzenie i utrzymywanie ośrodka pomocy społecznej, w tym zapewnienie środków na wynagrodzenia pracowników; przyznawanie i wypłacanie zasiłków stałych; opłacanie składek na ubezpieczenie zdrowotne określonych w przepisach o świadczeniach opieki zdrowotnej finansowanych ze środków publicznych.

Według art. 17 ust. 2 ups do zadań własnych gminy o charakterze dobrowolnym należą: przyznawanie i wypłacanie zasiłków specjalnych celowych; przyznawanie i wypłacanie pomocy na ekonomiczne usamodzielnienie w formie zasiłków, pożyczek oraz pomocy w naturze; prowadzenie i zapewnienie miejsc w domach pomocy społecznej i ośrodkach wsparcia o zasięgu gminnym oraz kierowanie do nich osób wymagających opieki; opracowanie i realizacja projektów socjalnych; podejmowanie innych zadań z zakresu pomocy społecznej wynikających z rozeznanych potrzeb gminy, w tym tworzenie i realizacja programów osłonowych; współpraca $\mathrm{z}$ powiatowym urzędem pracy $\mathrm{w}$ zakresie upowszechniania ofert pracy oraz informacji o wolnych miejscach pracy, upowszechniania informacji o usługach poradnictwa zawodowego i o szkoleniach oraz realizacji Programu Aktywizacja i Integracja, o którym mowa w przepisach o promocji zatrudnienia $\mathrm{i}$ instytucjach rynku pracy.

Ośrodek pomocy społecznej, wykonując zadania własne gminy w zakresie pomocy społecznej, kieruje się ustaleniami wójta (burmistrza, prezydenta miasta). Należy podkreślić szczególną pozycję kierownika ośrodka pomocy społecznej w zakresie wykonywania omawianych zadań własnych gminy. Zgodnie z art. 39 usg decyzje $\mathrm{w}$ indywidualnych sprawach $\mathrm{z}$ zakresu administracji publicznej wydaje wójt, o ile przepisy szczególne nie stanowią inaczej. Wójt może także upo- 
ważnić swoich zastępców lub innych pracowników urzędu gminy do wydawania decyzji administracyjnych (w imieniu wójta). $Z$ przepisów tych wynika domniemanie właściwości wójta w zakresie wydawania decyzji administracyjnych, które może być ograniczone przez przepisy ustawowe.

Ustawa o pomocy społecznej posługuje się w tej kwestii szczególną konstrukcją dekoncentracji obligatoryjnej. Punktem wyjścia jest przedstawione domniemanie właściwości. Artykuł 110 ust. 7 ups nakazuje jednak wójtowi udzielenie kierownikowi ośrodka pomocy społecznej upoważnienia do wydawania decyzji administracyjnych w indywidualnych sprawach z zakresu pomocy społecznej należących do właściwości gminy. Takie upoważnienie może być udzielone także innej osobie na wniosek kierownika ośrodka pomocy społecznej (art. 110 ust. 8).

Artykuł 18 ups stanowi, że obowiązkiem gminy w zakresie pomocy społecznej jest także wykonywanie zadań zleconych z zakresu administracji rządowej. Obejmuje to następujące sprawy: organizowanie i świadczenie specjalistycznych usług opiekuńczych w miejscu zamieszkania dla osób z zaburzeniami psychicznymi; przyznawanie i wypłacanie zasiłków celowych na pokrycie wydatków związanych z klęską żywiołową lub ekologiczną; prowadzenie i rozwój infrastruktury ośrodków wsparcia dla osób z zaburzeniami psychicznymi; realizacja zadań wynikających z rządowych programów pomocy społecznej, mających na celu ochronę poziomu życia osób, rodzin i grup społecznych oraz rozwój specjalistycznego wsparcia; przyznawanie i wypłacanie zasiłków celowych, a także udzielanie schronienia, posiłku oraz niezbędnego ubrania kategoriom cudzoziemców, określonym w art. 170 i 176 ustawy z dnia 12 grudnia 2013 roku o cudzoziemcach; przyznawanie i wypłacanie zasiłków celowych, a także udzielanie schronienia oraz zapewnianie posiłku i niezbędnego ubrania cudzoziemcom, którym udzielono zgody na pobyt ze względów humanitarnych lub zgody na pobyt tolerowany na terytorium Rzeczypospolitej Polskiej; wypłacanie wynagrodzenia za sprawowanie opieki.

Gmina, realizując zadania zlecone pomocy społecznej z zakresu administracji rządowej, kieruje się ustaleniami przekazanymi przez wojewodę (art. 110 ust. 2 ups).

5. Możliwość modyfikacji przedstawionego porząaku zadaniowo-kompetencyjnego w zakresie świadczenia pomocy społecznej w gminie wprowadziła ustawa z dnia 19 lipca 2019 roku o realizowaniu usług społecznych przez centrum usług społecznych ${ }^{14}$. Ustawę uchwalono w wyniku prezydenckiej inicjatywy ustawodawczej z listopada 2018 roku.

W uzasadnieniu do projektu tej ustawy ${ }^{15}$ wskazano między innymi, że jej zasadniczym celem jest rozwój i integracja systemu usług społecznych na poziomie lokalnym. Wzrost zapotrzebowania na usługi społeczne organizowane przez władze publiczne oraz oczekiwanie na wprowadzanie nowych ich rodzajów jest

14 Dz.U. poz. 1818.

15 Druk sejmowy nr 3040. 
wynikiem starzenia się społeczeństwa i osłabienia więzi międzypokoleniowych w rodzinie. Proponowane rozwiązania mają stworzyć ramy prawne ułatwiające gminom integrację i koordynację takich usług, przy wykorzystaniu zaproponowanego rozwiązania organizacyjnego, czyli centrum usług społecznych.

Powołano się na doświadczenia państw rozwiniętych, w tym Unii Europejskiej, gdzie stały rozwój usług społecznych jest przejawem tak zwanej inwestycyjnej polityki społecznej. Lokalne systemy świadczenia takich usług uważane są za podstawowe narzędzie kreowania polityki społecznej na poziomie lokalnym. Stąd niezbędna jest koordynacja poszczególnych polityk publicznych, integracja działania placówek i programów środowiskowego wsparcia usługowego. Tworzenie takich lokalnych systemów usługowych sprzyja rozwojowi współpracy międzysektorowej oraz wykorzystaniu potencjału organizacji sektora obywatelskiego i sektora ekonomii społecznej. Prowadzi to nie tylko do lepszego zaspokojenia potrzeb członków samorządowych wspólnot terytorialnych. Będzie to sprzyjało również ich integracji i wzrostowi spójności społecznej.

W uzasadnieniu powołano się na konieczność wprowadzenia proponowanych zmian, sygnalizowaną w Polsce w toku wdrażania programów społecznych po 2015 roku. Zgodnie z koncepcją projektu centra usług społecznych mają być tworzone $\mathrm{w}$ celu zaspokajania przez gminy potrzeb wspólnoty samorządowej w zakresie określonych w ustawie usług społecznych oraz ich koordynacji. Centrum ma być nowym rodzajem jednostki organizacyjnej gminy, nową instytucją polityki społecznej, służącą rozwojowi i integracji usług społecznych na poziomie lokalnym.

Stwierdzono, że utworzona w Polsce w latach dziewięćdziesiątych XX wieku sieć ośrodków pomocy społecznej odegrała pozytywną rolę w łagodzeniu negatywnych skutków ekonomicznych transformacji. W rozwiązaniach ustrojowych lokalnej polityki społecznej ustawy z dnia 29 listopada 1990 roku o pomocy społecznej ${ }^{16}$ popełniono wszakże błąd, polegający na utrwalaniu istniejących podziałów resortowych. Struktury publiczne spoza pomocy społecznej nie poddawały się próbom ich koordynacji przez placówki pomocy społecznej. Negatywną rolę w tym zakresie odegrały także instrumenty finansowo-prawne. Przekazywane środki budżetowe miały bowiem charakter celowy - były przeznaczone na wykonywanie zadań publicznych w różnych obszarach sfery społecznej, takich jak: pomoc społeczna, edukacja, pomoc osobom niepełnosprawnym itd. Powiatowe centra pomocy rodzinie skoncentrowały aktywność na realizacji własnych zadań ustawowych (opieka zastępcza, pomoc niepełnosprawnym), pozostawiając poza polem widzenia koordynację wsparcia mieszkańców przez lokalne instytucje, służby i organizacje. Nie wprowadzono więc zintegrowanych lokalnych systemów pomocy dziecku i rodzinie będących celami drugiej reformy samorządowej. W rezultacie ośrodki pomocy społecznej zaczęły prowadzić programy usług dla mieszkańców, wykraczające poza założoną selektywność wsparcia. Rozwój takich

16 Dz.U. Nr 87, poz. 506. 
programów napotykał i nadal napotyka na istotną barierę. Obowiązująca ustawa o pomocy społecznej ogranicza bowiem powszechny charakter programów wsparcia realizowanych w ośrodkach pomocy społecznej. W takiej sytuacji istniała potrzeba wprowadzenia na poziomie lokalnym niezbędnych zmian w zakresie świadczenia usług społecznych.

Projekt ustawy został przyjęty bez istotnych modyfikacji w procesie legislacyjnym ${ }^{17}$.

6. Zakres przedmiotowy ustawy obejmuje w zasadzie dotychczasowe zadania samorządu gminnego. Ustawa przewiduje tylko możliwość poszerzenia zakresu usług świadczonych przez centrum na podstawie porozumienia zawartego $\mathrm{z}$ powiatem, którego przedmiotem mogą być niezdefiniowane $\mathrm{w}$ ustawie usługi społeczne będące zadaniami własnymi powiatu oraz zadaniami z zakresu administracji rządowej zleconymi powiatowi (art. 3 ust. 2).

Ustawa nie definiuje usług społecznych, lecz wylicza ich rodzaje w art. 2 ust. 1 jako działania z zakresu: polityki prorodzinnej, wspierania rodziny, systemu pieczy zastępczej, pomocy społecznej, promocji i ochrony zdrowia, wspierania osób niepełnosprawnych, edukacji publicznej, przeciwdziałania bezrobociu, kultury, kultury fizycznej i turystyki, pobudzania aktywności obywatelskiej, mieszkalnictwa, ochrony środowiska, reintegracji zawodowej i społecznej. Ich celem jest zaspokajanie potrzeb wspólnoty samorządowej i świadczenie w formie niematerialnej bezpośrednio na rzecz osób, rodzin, grup społecznych, grup mieszkańców o określonych potrzebach lub ogółu mieszkańców gminy. Jak się wydaje, jest to katalog zamknięty. W art. 2 ust. 2 ustawa przyjmuje natomiast w otwartym katalogu, że usługami społecznymi są w szczególności działania podejmowane na podstawie wymienionych 17 ustaw $^{18}$, bez odwołania się do ich konkretnych

17 Druk sejmowy nr 3590.

18 Według tego przepisu usługami społecznymi są w szczególności działania podejmowane na podstawie: 1) ustawy z dnia 9 czerwca 2011 roku o wspieraniu rodziny i systemie pieczy zastępczej (Dz.U. z 2019 r. poz. 1111 i 924); 2) ustawy z dnia 29 lipca 2005 roku o przeciwdziałaniu przemocy w rodzinie (Dz.U. z 2015 r. poz. 1390, oraz z 2019 r. poz. 730); 3) ustawy z dnia 12 marca 2004 roku o pomocy społecznej (Dz.U. z 2019 r. poz. 1507, 1622 i 1690); 4) ustawy z dnia 27 sierpnia 2004 roku o świadczeniach opieki zdrowotnej finansowanych ze środków publicznych (Dz.U. z 2019 r. poz. 1373, 1394, 1590, 1694 i 1726); 5) ustawy z dnia 19 sierpnia 1994 roku o ochronie zdrowia psychicznego (Dz.U. z 2018 r. poz. 1878, oraz z 2019 r. poz. 730 i 1690); 6) ustawy z dnia 11 września 2015 roku o zdrowiu publicznym (Dz.U. z 2018 r. poz. 1492, oraz z 2019 r. poz. 447); 7) ustawy z dnia 26 października 1982 roku o wychowaniu w trzeźwości i przeciwdziałaniu alkoholizmowi (Dz.U. z 2018 r. poz. 2137 i 2244, oraz z 2019 r. poz. 730); 8) ustawy z dnia 29 lipca 2005 roku o przeciwdziałaniu narkomanii (Dz.U. z 2019 r. poz. 852 i 1655); 9) ustawy z dnia 27 sierpnia 1997 roku o rehabilitacji zawodowej i społecznej oraz zatrudnianiu osób niepełnosprawnych (Dz.U. z 2019 r. poz. 1172, 1495 i 1696); 10) ustawy z dnia 14 grudnia 2016 roku Prawo oświatowe (Dz.U. z 2019 r. poz. $1148,1078,1287,1680$ i 1681); 11) ustawy z dnia 20 kwietnia 2004 roku o promocji zatrudnienia i instytucjach rynku pracy (Dz.U. z 2019 r. poz. 1482 i 1622); 12) ustawy z dnia 13 czerwca 2003 roku o zatrudnieniu socjalnym (Dz.U. z 2019 r. poz. 217 i 730); 13) ustawy z dnia 25 października 1991 roku o organizowaniu i prowadzeniu działalności kulturalnej (Dz.U. z 2018 r. 
przepisów. Jest to częściowo uzupełnione w rozdziale 6 ustawy. Ograniczają się one w zasadzie do wskazania jako podmiotu właściwego - centrum usług społecznych, obok ośrodka pomocy społecznej, a także jako organu właściwego - dyrektora centrum usług społecznych, obok kierownika ośrodka pomocy społecznej. Niezależnie od tego art. 80 ustawy dubluje tę regulację, przyjmując, że ilekroć w przepisach odrębnych jest mowa o ośrodku pomocy społecznej, należy przez to rozumieć centrum usług społecznych; jeśli o kierowniku ośrodka pomocy społecznej, należy przez to rozumieć dyrektora centrum usług społecznych, gdy centrum usług społecznych powstało w wyniku przekształcenia ośrodka pomocy społecznej.

Ustawa reguluje w rozdziale 3 tworzenie, zadania i zasady działania centrum usług społecznych. Gmina może zatem utworzyć i prowadzić centrum w celu zaspokajania potrzeb wspólnoty samorządowej na określone usługi społeczne, mieszczące się w zakresie zadań własnych gminy, oraz przejętych od powiatu, a także ich koordynowania. Centrum może być utworzone dla jednej gminy, dla dwóch lub większej liczby gmin. W pierwszym przypadku następuje to w drodze przekształcenia istniejącego gminnego ośrodka pomocy społecznej. W drugim przypadku centrum tworzone jest przez utworzenie w jednej z gmin, na podstawie zawartego porozumienia ${ }^{19}$, nowej jednostki organizacyjnej, odrębnej od funkcjonującego $\mathrm{w}$ tej gminie ośrodka pomocy społecznej. W miastach powyżej stu tysięcy mieszkańców centrum może być utworzone w drodze jednej z powyższych procedur. Ustawa określa minimalny zakres zadań do przekazania tworzonemu centrum usług społecznych (art. 10). Rodzaj i zakres zadań, w tym usług społecznych, przekazanych do realizacji centrum oraz szczegółową organizację centrum określa statut centrum nadany przez radę gminy w drodze uchwały (art. 12).

Celem ustawy jest zatem skupienie w ramach jednej struktury organizacyjnej systemu usług społecznych dotychczas świadczonych w sposób rozproszony w gminie bądź w większej liczbie gmin, z poszerzeniem o ewentualne przejęcie od powiatu w drodze porozumienia świadczenia niektórych usług. Bazą organizacyjną takiego układu ma być ośrodek pomocy społecznej przekształcony w jednostkę organizacyjną o szerszym niż dotychczas zakresie działania. Może to także nastąpić w drodze utworzenia nowej jednostki organizacyjnej.

Ustawa stanowi w art. 13, że do zadań centrum należy w szczególności: zaspokajanie potrzeb wspólnoty samorządowej w zakresie usług społecznych przekazanych do realizacji centrum, w tym określonych w programie usług społecznych; prowadzenie rozeznania potrzeb i potencjału wspólnoty samorządowej w zakresie

poz. 1983, oraz z 2019 r. poz. 115, 730 i 1696); 14) ustawy z dnia 25 czerwca 2010 roku o sporcie (Dz.U. z 2019 r. poz. 1468 i 1495); 15) ustawy z dnia 9 października 2015 roku o rewitalizacji (Dz.U. z 2018 r. poz. 1398, oraz z 2019 r. poz. 730 i 1696); 16) ustawy z dnia 4 lutego 2011 roku o opiece nad dziećmi w wieku do lat 3 (Dz.U. z 2019 r. poz. 409 i 730); 17) ustawy z dnia 5 grudnia 2014 roku o Karcie Dużej Rodziny (Dz.U. z 2019 r. poz. 1390).

19 Art. 11 ustawy. 
usług społecznych; opracowywanie diagnozy potrzeb i potencjału wspólnoty samorządowej w zakresie usług społecznych; realizowanie programu usług społecznych, w tym kwalifikowanie osób zainteresowanych do korzystania z usług społecznych określonych w programie usług społecznych oraz opracowywanie i monitorowanie realizacji indywidualnych planów usług społecznych; realizowanie innych niż usługi społeczne zadań przekazanych do realizacji centrum, w tym zadań z zakresu pomocy społecznej; podejmowanie działań na rzecz integracji i wspierania rozwoju wspólnoty samorządowej z wykorzystaniem potencjału tej wspólnoty, w tym organizowanie działań samopomocowych, wolontaryjnych i sąsiedzkich stanowiących uzupełnienie usług społecznych (działania wspierające); opracowywanie standardów jakości usług społecznych określonych w programie usług społecznych, w przypadku braku określenia tych standardów w obowiązujących przepisach, oraz ich wdrażanie; podejmowanie działań na rzecz rozwoju i koordynacji usług społecznych, w tym przez nawiązywanie współpracy z organami administracji publicznej, organizacjami pozarządowymi i innymi podmiotami; gromadzenie, aktualizowanie i udostępnianie informacji o usługach społecznych realizowanych na obszarze gminy tworzącej centrum oraz gminy będącej stroną porozumienia.

$\mathrm{Z}$ przedstawionego wyliczenia wynika, że zadaniem centrum usług społecznych jest nie tylko świadczenie usług, ale także ich koordynacja, czyli harmonizowanie świadczenia usług centrum z aktywnością innych usługodawców publicznych bądź prywatnych w gminie. Działalność centrum wykracza zatem poza zakres administracji świadczącej czy administracji usług w utrwalonym znaczeniu $\mathrm{w}$ polskiej nauce prawa administracyjnego ${ }^{20}$. Jest to bowiem także stwarzanie warunków do ich świadczenia, czyli działania organizujące usługi ${ }^{21}$.

W tym celu wprowadzono do ustawy rozwiązania mające umożliwić realizację takich zadań. Artykuł 4 ustawy daje radzie gminy w ramach zadań dobrowolnych gminy kompetencję uchwalania programu usług społecznych bądź większej liczby takich programów, określających usługi społeczne wynikające z potrzeb wspólnoty samorządowej. Według ustawy taki program jest aktem prawa miejscowego. Jest to pewne novum, zważając na to, że programów nie uznaje się za akty normatywne. Można więc stwierdzić, że jest to akt prawa miejscowego jedynie w sensie formalnym.

Adresatami usług społecznych ujętych w programie, według art. 5 ustawy, mogą być osoby, rodziny, grupy społeczne, grupy mieszkańców o określonych potrzebach lub ogół mieszkańców gminy. Jednym ze źródeł opracowywania programu usług społecznych jest diagnoza potrzeb i potencjału wspólnoty samorządowej w zakresie takich usług, opracowywana przez centrum. Według niewyczerpującego wyliczenia program usług społecznych zawiera: nazwę i cel programu;

20 I. Sierpowska, Pomoc społeczna jako administracja świadczaca. Studium administracyjnoprawne, Warszawa 2012, s. 11.

21 T. Kuta, Funkcje współczesnej administracji i sposoby ich realizacji, Wrocław 1992, s. 19. 
okres realizacji programu; opis potrzeb uzasadniających realizację programu; charakterystykę i przewidywaną liczbę osób objętych programem; określenie usług społecznych oferowanych w programie; warunki i tryb kwalifikowania osób zainteresowanych do korzystania z usług społecznych określonych w programie; wysokość opłaty za usługi społeczne, osoby uprawnione do uzyskania ulg w opłacie za usługi społeczne i wysokość tych ulg, jeżeli program przewiduje opłatę lub ulgi w opłacie za usługi społeczne; sposób dokumentowania spełniania warunków oraz uprawnień do uzyskania ulg w opłatach; dane osobowe niezbędne do kwalifikowania osób zainteresowanych do korzystania z usług społecznych określonych w programie; organizację programu, w tym etapy jego realizacji; sposób monitorowania i oceny programu oraz mierniki efektywności jego realizacji; budżet programu oraz źródła jego finansowania.

Ustawa zastrzega, że programy usług społecznych uregulowane w przepisach odrębnych nie mogą uchybiać tym przepisom, w szczególności standardom ich świadczenia czy zasadom ich przyznawania. Nie mogą być także sprzeczne z innymi programami, przyjętymi przez gminę.

Ustawa definiuje w art. 7 pojęcia realizatora i wykonawcy programu usług społecznych. Przyjmuje, że realizatorem jest centrum. Wykonawcą może być urząd gminy lub inna jednostka organizacyjna gminy, w tym także centrum lub organizacja pozarządowa czy podmiot, o którym mowa w art. 3 ust. 3 ustawy z dnia 24 kwietnia 2003 roku o działalności pożytku publicznego i o wolontariacie ${ }^{22}$, wyłoniony na podstawie tej ustawy, podmiot wyłoniony na podstawie ustawy z dnia 29 stycznia 2004 roku Prawo zamówień publicznych ${ }^{23}$ lub podmiot wykonujący działalność leczniczą w rozumieniu ustawy z dnia 15 kwietnia 2011 roku o działalności leczniczej ${ }^{24}$.

Ustawa zawiera $\mathrm{w}$ art. 14 obszerny katalog zasad wykonywania zadań przez centrum usług społecznych, czyli z uwzględnieniem dobra osób uprawnionych, standardów świadczenia usług, dostosowania do potrzeb wspólnoty samorządowej, współdziałania z organizacjami trzeciego sektora, dążenia do wzmocnienia więzi społecznych oraz integracji i rozwoju wspólnoty samorządowej (zasada wzmacniania więzi społecznych).

7. Ustawa jest normatywnym rozwiązaniem o charakterze fakultatywnym, zawierającym propozycję modelu organizacji świadczenia usług społecznych $\mathrm{W}$ gminie. $\mathrm{W}$ tym sensie respektuje władztwo organizacyjne gmin. $\mathrm{Z}$ drugiej strony, jeśli zostanie przyjęta, rozwiązania w niej zawarte wiążą władze gminy, z ograniczonymi możliwościami odstąpienia od niektórych bądź modyfikowania ich. To może zniechęcać do jej przyjęcia. Ustawa nie poszerza zakresu zadań gmin i kompetencji ich organów, a jedynie je porządkuje i organizuje. Przyjmuje formy działania czy procedury już uregulowane prawnie, na przykład porozumie-

22 Dz.U. z 2019 r. poz. 688 i 1570.

23 Dz.U. z 2018 r. poz. 1986 z późn. zm.

24 Dz.U. z 2018 r. poz. 2190 z późn. zm. 
nia w sprawie przekazywania zadań przez powiat gminie przewidują także art. 4 ust. 5 oraz art. 5 usp. Planowanie współdziałania z organizacjami pozarządowymi $\mathrm{w}$ gminie jest przewidziane $\mathrm{w}$ art. $5 \mathrm{n}$. ustawy o organizacjach pożytku publicznego i wolontariacie, stanowiących podstawę uchwalania przez radę gminy programów współpracy z tymi organizacjami.

Niektóre zasobniejsze finansowo gminy w Polsce, w ramach obowiązującego porządku prawnego poprzedzającego omawianą ustawę, zorganizowały już bądź organizują centra świadczeń społecznych podobne do uregulowanych w ustawie, mając przy tym większą swobodę w kształtowaniu ich zadań, organizacji i zasad funkcjonowania.

Tworzenie centrów usług społecznych, czyli dokonywanie zmian organizacyjnych, wbrew założeniom ustawy, tylko częściowo rozwiąże problemy wynikające $\mathrm{z}$ rosnących potrzeb w zakresie poszerzania oferty, organizowania i świadczenia przez administrację publiczną usług społecznych. Jak zawsze w administracji świadczącej ważne jest jej finansowanie. Dla rozwoju i funkcjonowania systemu usług społecznych istotnym czynnikiem są warunki finansowe. Obecnie takie środki w ograniczonej wysokości mogą być przyznane jedynie na organizację centrów, a nie na ich działalność. Jeżeli polepszy się finansowanie, w szczególności pomocy społecznej, można oczekiwać zmian organizacyjnych w samorządowym systemie świadczenia usług społecznych. Powstaje jednak pytanie, czy odbędzie się to na podstawie omawianej ustawy, czy z wykorzystaniem doświadczeń praktyki samorządowej.

\title{
CENTRE FOR SOCIAL SERVICES AS AN ORGANISATIONAL FORM OF PRESTATIVE ADMINISTRATION
}

\author{
Summary
}

The concept of a centre for social services was introduced into the legal framework pursuant to the act of 19th July 2019 on the provision of social services by a centre for social services. It is an organisational unit established voluntarily by a commune council, providing social services beyond social assistance, which were operated in the commune so far by various entities, a social welfare centre in particular, and also taken over from a district on the basis of an agreement. As a rule, the centre is created by way of reorganising a communal social welfare centre, and provides services for one commune. The centre may also be established as a new organisational unit of one or several communes, appointed to render services in their territory. In this regard the act aims at creating order, as it refers to or indicates applicable legal regulations of other acts. The range of the tasks entrusted to the centre for social services also includes the coordination of social services provided by other entities in the territory where the centre operates. For that purpose the act introduces legal mechanisms which aim at exercising that function, such as social services programming or local community organisation planning in particular.

Keywords: public administration, prestative administration, social assistance, social security, social services, centre for social services, local community organiser 


\section{BIBLIOGRAFIA}

Banaszak B., Prawo konstytucyjne, Warszawa 2008.

Jaworska-Dębska B., Glosa do wyroku NSA z dnia 21 listopada 2013 r., II OSK 1887/13, „Samorząd Terytorialny" 2015, nr 3, s. 87-94.

Jończyk J., Prawo zabezpieczenia społecznego, Kraków 2003.

Kuta T., Funkcje współczesnej administracji i sposoby ich realizacji, Wrocław 1992.

Miemiec M., Prawo pomocy społecznej, [w:] Materialne prawo administracyjne, red. M. Miemiec, Warszawa 2019, s. 122-160.

Muszalski W., Prawo socjalne, Warszawa 2006.

Sierpowska I., Pomoc społeczna jako administracja świadczaca. Studium administracyjnoprawne, Warszawa 2012.

Sierpowska I., Prawo pomocy społecznej, Warszawa 2008. 